\title{
Organization of honeybee colonies: characteristics and consequences of a superorganism concept
}

\author{
Robin F.A. Moritz ${ }^{\mathrm{a}}$, Stefan Fuchs ${ }^{\mathrm{b} *}$ \\ ${ }^{a}$ Institut für Zoologie, Martin-Luther-Universität, \\ Kröllwitzer Str. 44, D-06099 Halle/Saale, Germany \\ bInstitut für Bienenkunde, Universität, Frankfurt/Main, \\ Karl-von-Frisch-Weg 2, 61440 Oberursel, Germany
}

(Received 24 September 1997; accepted 10 December 1997)

\begin{abstract}
The colonial organization of honeybees reveals numerous analogies to multicellular organisms which makes it tempting to use the term superorganism. The sterile workers fulfill the role of the somatic cells in organisms with intricate and complex interactions. These interactions are under partial control of hierarchical signals (pheromones) which are primarily used for global information of the colony. The majority of the activities in the colony is, however, regulated through local decision making and through self-organized processes which are regulated through worker threshold response variability. In honeybees this is enhanced through the highly polyandrous mating system which allows for wide genotypic variance and the presence of genetic specialists. Although both individual and colony level selection can be observed in honeybees the latter seems to be the predominant selective force. This is similar to organismic selection where selection among or within cells is less relevant to evolutionary processes than fitness at the organismic level. (C) Inra/DIB/AGIB/Elsevier, Paris
\end{abstract}

social organization / superorganism / division of labor / self-organization / polyandry / Apis mellifera

\section{INTRODUCTION}

Honeybees live in tight societies, where every individual is highly integrated behaviorally and dependent in its survival and reproduction. The social group is an essential entity for inclusive fitness of any given honeybee, and the fitness of each member is zero if deprived of the group context. In a colonial context, however, honeybees are extremely efficient. They can regulate intracolonial environment such that they buffer even exceptional fluctuations in ambient conditions. Their ability of thermal intracolonial control and their ability to store nectar and pollen

\footnotetext{
* Correspondence and reprints
}

Tel.: (49) 617121 278; fax: (49) 6171 25 769; e-mail: s.fuchs@em.uni-frankfurt.d400.de 
allows them to sustain extended periods of dearth and cold. Clusters of bees are able to survive ambient temperatures as low as $-80^{\circ} \mathrm{C}$ (Southwick, 1988). As a consequence of this homeostatic ability, Apis mellifera $\mathrm{L}$. was able to colonize most diverse habitats ranging from northern Europe to the Cape of South Africa (Ruttner, 1988; Smith, 1991).

\section{ORGANISMS AND SUPERORGANISMS}

Honeybee colonies have often been called 'superorganisms' in analogy to a complex higher organism being composed of numerous single cells (Wheeler, 1928; Seeley, 1989; Moritz and Southwick, 1992). There is obviously something tempting in this view, and certainly beekeepers prefer to think of bees in terms of colonies rather than individuals. Although many of the principal features may also be found in other socially organized animals such as wolf packs or groups of mongoose, there is something special about the tightness of bee colonies which closely resembles at least more primitive multicellular organisms, and thus seems to call for a term such as superorganism.

Although such a definition may at first glance have heuristic appeal, the issue of whether the use of the term is helpful in understanding the biological processes governing life history of honeybees remains controversial. For a critical evaluation, there are at least three aspects to consider: analogies in structure, analogies in the perspective of genetics and selection, and analogies in organizational principles. We deal with these each in turn and finally show how we think the particular organizational demands may affect genetic transmission.

\subsection{Analogies in structure}

The first and basic analogy between an organism and a honeybee colony is that both are composed of single units, cells and bees, respectively, which depend on the functioning of the higher unit for their survival. Individual cells have life cycles within the organism, and isolated cells are usually unable to develop outside the organismic environment. It requires focused technical efforts to obtain controlled cell growth and differentiation with in-vitro cell culture. The development of an individual honeybee does not differ much from that of any other holometabolic insect in principle, yet there are dramatic biotic constraints which govern the development of a honeybee. Most evident is the developmental pathway from egg to adult which can only occur in the presence of large numbers of other bees. The large body of workers is instrumental for brood rearing. They provide the combs where the queen deposits the eggs. They feed and foster the larvae and maintain the correct temperature for brood development. They also provide a nest site which is of crucial importance for temperature control and protection of the stores and the brood against predators. Thus the successful completion of the above developmental cycle depends intricately on the presence of an intact colony comprised of a nest cavity, combs and a large number of other bees.

The next structural analogy is differentiation. During development of an organism, cell lines are extremely versatile and can specialize into an amazing variety of different forms. Although something similar is observed in many ants, which have distinct castes of soldiers, nurses or foragers, nothing of this kind is found in honeybees. The only exception is the differentiation into workers and reproductives. This, however, does not imply that there is no specialization among worker honeybees. A honeybee colony also 
requires a variety of tasks to be performed. Worker specialization is, however, not solved through phenotypic castes, and we will deal with that crucial aspect later in discussing organizational principles. The structural analogy between honeybee colony and organisms is in the degree of local organization, resembling the structuring of an organism's cells into a composite whole with different organs. In a bee colony there are distinct regions for proliferation (the brood nest) and for storage of carbohydrates or proteins. These might be seen as analogues of if not organs, then certainly a primitive organism's shape.

Another striking analogy is that between workers in a colony and somatic cells in an organism. Both have sacrificed their direct fitness in support of other entities: the sexual reproductives in the case of honeybees, and the germ line cells in the case of organismic cells. Most honeybee larvae develop into workers, which usually neither reproduce nor compete for reproductive success. This is very different indeed to comparable solitary organisms where interindividual competition for resources and reproduction is the rule.

Although these analogies seem convincing at first sight, they are based on plain phenological and very proximate similarities. As such, they are least telling for ultimate arguments and may invite misunderstandings rather than insights. We therefore proceed to investigate analogies which are based on more general principles, rather than on possibly accidental resemblances.

\subsection{Analogies in evolutionary mechanisms}

Attitudes to the superorganismic concept have undergone considerable change. Evolutionary biologists have proposed rather polarized views during the past decades. In reaction to the refutation of non-Darwinian group selection ideas (Wynne Edwards, 1962), the individual was firmly reestablished as the unit of selection (Williams, 1966; MaynardSmith, 1964). Groups were banned from the selection arena, and consequently there was no longer any room left for superorganisms. With concepts of inclusive fitness (Hamilton, 1964a,b), and genes as primary units of selection (Dawkins, 1976) this individual-centered view softened and group selection regained credibility (Wilson, 1975, 1977). Subsequently, the superorganismic view regained momentum (Wilson and Sober, 1989; Seeley, 1989). In defining gene action as primarily a logical relation between a replicator and an outside effect, Dawkins (1982) further devaluated the role of the individual to that of a mere vehicle for gene replication. This radical view removed all barriers to regard colonial properties as gene actions which might be traced via individual behavioral traits to the genes in the individuals. Indeed Hunt et al. (1995) were able to map quantitative trait loci with individuals that influenced pollen hoarding at the colonial level, thus proving the practical value of this concept of the colony as an 'extended phenotype' (Dawkins, 1982).

This change in attitude invited a reevaluation of the significance of individual organisms for evolution. Dawkins (1982) pointed out that genetic bottlenecks in the transmission of genes from generation to generation are a necessary condition for the evolution of stable units with minimal or reduced intraorganismic conflict. In honeybee colonies, this condition is met, as genes are transmitted through the bottleneck of a queen and a few drones, from which all individuals of the next-generation superorganism are derived.

Critics of the superorganism concept have correctly pointed out that there is a conceptual difference between coopera- 
tion of somatic cells with identical genomes and cooperative behavior of genotypically different organisms. In the latter case there is a strong conflict potential between direct individual reproduction and fitness gains through kin selection. Each individual worker has to decide how to invest its individual resources in the colony. Should it favor females over males? Should it behave nepotistically to related nestmates? For the evolution of entities, genetic bottlenecks are logically more important than the internal distribution of the genes over the entities. There will be greater potential for intraorganismic conflict with wider genetic bottlenecks, and smaller if these are narrow. The extreme degree of polyandry of the honeybee queen may yield a relatively wide bottleneck if queens of many patrilines are reared. However, this seems to be a weak argument against the superorganism concept since in a huge variety of organisms this bottleneck is not minimized either, by the transmission of two or more sets of genes in the formation of a zygote.

While these general considerations do strengthen the superorganism analogy, further support comes from the understanding of the evolution of simple multicellular organisms. Slime molds provide an example where the component cells move independently, until they aggregate and differentiate into somatic stalk cells and germ line spore cells (Bonner, 1995). In a radical reevaluation of early evolution, Buss (1987) envisaged organisms as lines of cells, competing for proliferation and access to the germ line. He stated that organismic selection is a two-level process, acting on cell lines and organisms, with possibly conflicting 'interests' and an increasing ability of organisms to control the selfish tendencies of their cell lines. It is thus an interesting twist in the discussion of the superorganism analogy, that it is recently supported by the discovery of the similarity of organisms to superor- ganisms, with two-level selection considerations for organisms strikingly familiar to the student of insect societies. The main support of this analogy thus is that the higher-level selection outweighs the lowerlevel selection. This is certainly true in honeybees which show remarkable low intracolonial conflict in spite of a huge conflict potential (Visscher, 1998).

\subsection{Analogies in organizational principles}

The organization in multicellular organisms is characterized by the cooperation of thousands of subunits towards the fulfillment of the multitude of different functions crucial for the welfare of the organism. It seemed to be clear to Wilson EO (1975) that: "the remarkable qualities of social life are mass phenomena that emerge from the meshing of these simple individual patterns by means of communication". So, how do the mass phenomena emerge and, what type of communication and individual patterns, if any, are behind these in honeybees?

Two organizational principles can be observed in organisms. One is the coordination of the different cell functions, the other is the specialization of cell groups for different purposes with a differentiation into highly specialized tissues. We want to show that striking similarities exist to the organizational principles found in honey bees. We also want to emphasize some differences. The coordination between cells and between honeybee workers follow surprisingly similar general patterns, which involve self-organization, local decisions, feedback loops, non-linear interactions and central control, but differ in the relative contribution of these components. Differentiation and specialization among honeybee workers are achieved by temporal castes and genetic variation. This latter process may be an important cue to 
understand some peculiarities in honeybee reproductive biology.

\subsection{Coordination by self-organization and local decisions}

Cells in organisms respond to local conditions without 'knowing' about the global condition of the organism. Many examples of self-organizing processes are found in developmental biology, where the cells react to the immediate conditions defined by their environment, in part formed by the neighboring cells. Ordered structures and responses emerge as a result of local interactions, rather than from centralized control.

Of course a global knowledge of the state of the colony and its environment might be quite helpful for an individual bee to decide whether or not to participate in a certain task. However, it is extremely unlikely that any individual in the colony has such knowledge at any given time. Decisions are much more likely to be made on the basis of local stimuli. The most famous local decisions are those resulting from the dance language (von Frisch, 1967). The returning forager recruits locally other workers to visit the same food source. Intensity of foraging and switching between resources is mediated by the perception of local stimuli which are correlated to colony needs and food source profitability (Seeley, 1986), rather than by direct perception of these conditions. Many others mechanisms have been described. Studying water foragers, Lindauer (1954) found that the regulation of cooperative behavior is not governed through a global knowledge, but rather by very simple local rules. Individual bees respond to simple local behavioral interactions with nest mates or their local nest environment to start, continue, or stop a specific task (Seeley, 1989, 1995; Camazine, 1991; Watmough and
Camazine, 1995; Robinson and Page, 1989). The queen does not decide from a global knowledge of all empty drone and worker cells in the brood nest area, whether to lay a drone or worker egg. Before she deposits an egg, she inspects cell by cell and measures the cell width to determine whether to lay a male or female egg (Koeniger, 1970) and thus responds to a local stimulus threshold, egg presence and cell diameter. Equally, comb usage for pollen and nectar (Camazine et al., 1990) and comb construction follow local decision rules which are based on stimulus thresholds. Such self-organized patterns have been suggested to play a very prominent role in the organization of complex systems [reviewed by Kauffman (1993)]. The idea is that on the basis of very simple rules complex patterns emerge that result in seemingly 'intelligent' cooperation. In honeybees self-organized patterns have been suggested for foraging (Camazine and Sneyd, 1991), comb usage (Camazine, 1991) and colonial circadian rhythms (Moritz and Kryger, 1994). Using a Boolean network, Page and Mitchell (1991) showed that ordered group structures and patterns can easily emerge from random aggregations of individuals in honeybee colonies. Clearly self-organization as a mechanism is common in complex systems and a priori has nothing to do with evolution (Page and Mitchell, 1989, 1998). Also abiotic complex systems tend to fall into organized patterns which are clearly free of fitness functions (Prigogine and Stengers, 1980). There is no reason to assume that self-organization as a mechanism is the result of selection in social systems, it is rather predicted by the system complexity itself. Self-organization in insect colonies is not surprising, on the contrary it would be extremely odd not to find self-organized patterns. Nevertheless, we would like to clearly point out that this does not mean that evolution does not act upon self-organized patterns in honeybees. The self-organized structures shape the 
colonial phenotype and will, therefore, be affected by natural selection. One possibility to tune colonial phenotypes are shifts in the overall stimulus threshold framework in the colony. Such changes can cause dramatic variability in pattern formation as shown by Hunt et al. (1995) for pollen foraging. Selection may then modify response levels and even shape nonadditive group behavior. Composite groups of honeybees often do not express the arithmetic mean behavior of their single tendencies, but instead show distinctly higher or lower expression levels than expected in an additive model (Trump et al., 1967; Moritz and Hillesheim, 1989; Moritz and Southwick, 1987; GuzmánNovoa and Page, 1994; Oldroyd et al., 1992; Fuchs and Schade, 1994).

\subsection{Coordination by feedback loops and non-linear interactions}

The homeostatic abilities of honeybee societies thus do not demand any kind of global control. Simple feedback loops can emerge as a property of the self-organized structures. For example the individual heat production of the surface bees in a bee cluster, removes the cold temperature stimulus for neighboring workers, causing a seemingly well-organized temperature control (Watmough and Camazine, 1995). One mechanism to explain such nonlinear behavioral interactions is through recurrent feedback loops which let the performance of one individual affect those of others. The mechanism underlying the alarm response may give us a simple example of such a mechanism. Defensive flights can be released by swift moving dark objects (Stort, 1974). The attacking bee releases the alarm pheromone which attracts other bees and reduces the response threshold for attacks. If the target stays in place more bees will release alarm pheromone, further reducing the stimulus threshold, and even more bees will attack, eventually resulting in the extreme mass attacks known from African and Africanized bees in the tropics (Collins et al., 1980). If the stimulus disappears conditions return to normal threshold levels. This example seems easy to understand because we know the behavioral basis which is under pheromone control. In most cases no pheromone will be involved but the principle will be the same. Workers are engaged in a specific activity and by doing so, modify the local conditions to exceed the stimulus response threshold of other workers (positive feedback). Also the opposite can be possible: the activity of a worker reduces the stimulus below the response threshold which then stops being involved in that task. Let us look at a possible mechanism for the regulation of guarding as a hypothetical example to illustrate how an individual worker's activity can be regulated by individual response thresholds. Let us assume the workers of a given colony have a threshold of five guard workers for the task of guarding. Thus if a worker passes the flight entrance and notices less than five workers, it will switch from its current task to guarding. As soon as five workers are present, no further workers will be recruited for guarding because the threshold is reached. The system becomes dynamic if we consider a decline in the behavioral threshold of the guards over time. If, for example, after 10 min of guarding the threshold for the critical number of guards drops to four (a mechanism similar to habituation), the first worker will leave the guard group and choose a different task [perhaps the most favorite task which is doing absolutely nothing, Lindauer (1952)]. A new worker with a high threshold will now be recruited to the reestablish the 'correct' number of guards, causing a turnover in guarding bees. Thus a complex system of seemingly intelligent division of labor can emerge through variable and dynamic response thresholds of individual workers. 


\subsection{Coordination by hierarchical control structures}

Higher organisms are characterized by the ability to release hierarchically controlled global signals which regulate cell activity. For example, hormones can be released that elicit specific reactions in certain organs. Neuronal control is an even stronger example of hierarchical decisions. Clearly global signals cannot sufficiently organize the full complexity of the colony. In fact they only modify the existing patterns created by self-organization and local decisions. Compared to the pronounced central control in many higher organisms, central control is rather weakly developed in honeybee societies. We find no rapid electrical communication pathways in honeybee colonies, but several ways of chemical communication have evolved which are of prime significance for regulating colonial life [for a review see Free (1987)]. The best example of such hierarchical signals in honeybees is the queen's mandibular gland pheromone which signals to the colony members the presence of the queen and releases a variety of specific reactions in the workers (Winston et al., 1989, 1990, 1991; Kaatz et al., 1992a,b; Engels et al., 1993). Indeed one is tempted to see this as a superb evolutionary step towards coordinated colonial life.

Pheromones are most often used in honeybee communication for essential messages which require swift global reactions. A typical example for such a 'releaser' pheromone is the alarm communication in workers. Pheromone release elicits swift recruitment of a large number of workers, and lowers their behavioral threshold for defensive stinging flights (Maschwitz, 1964a,b). Several other pheromones are currently known in honeybee communication (Moritz and Southwick, 1992) yet clearly in light of the highly complex interactions the number of identified pheromones seems com- paratively small. Though honeybees have evolved a number of communication signals to control their society, these may be less important than initially thought, and restricted to the modification of local decisions of workers.

\subsection{Differentiation and specialization by division of labor}

It is a common feature of higher organisms, that their cells differentiate into various types, serving different purposes. It is the amazing versatility of the cell's basic structures, that allows for the complexity of the organismic world. In contrast, the lack of apparent differences between the workers composing the complexity of honeybee colonies is rather surprising. If we look at ant societies we find a huge phenotypic plasticity with a great variability of different castes. Soldiers, foragers, majors, minors: castes in ants can cause individuals to vary orders of a magnitude (Wilson and Hölldobler, 1990). The presence of many discrete classes in the complex systems enhances the ease of pattern formation and prevents chaotic system reactions. Page and Mitchell (1991) argue that threshold diversity stabilizes the colony by avoiding complexity catastrophes. So what about honeybees?

Worker bees are all very similar and phenotypic variability dividing the workers into specific castes seems absent. Perhaps constraints due to the flight ability prevent the evolution of extreme phenotypic caste differences such as those observed in ants. While distinct worker castes are lacking, interindividual behavioral threshold variability can nevertheless be very pronounced as we discussed above. Two principal mechanisms for task specialization are known. First, division of labor is controlled through the wellknown temporal polyethism (Rösch, 1927; Lindauer, 1952; Seeley, 1982), 
which provides an extremely flexible system of worker allocation (Rösch, 1930). More recently, however, it has been repeatedly shown that task division is also subject to genetic variability within age cohorts (Moritz and Hillesheim, 1989; Page and Robinson, 1991; Robinson and Page, 1988). Specialists for certain tasks are expected to have a specifically low threshold for this specific task (Robinson and Page, 1989), and members of specific subfamilies in the colony proved to show preferences for specific tasks. This is most extreme in the Cape honeybee $A . m$. capensis where almost all of the laying workers in a colony originate from a single subfamily (Moritz et al., 1996). Genotypic variability is thus clearly a factor contributing to intracolonial response threshold variability.

If pattern formation is critical for the functioning of the complex colony, then evolution should favor mechanisms that facilitate self-organization. Genotypic variability would be a possible way to achieve this goal. In honeybees threshold variability is not achieved through a wide array of phenotypic castes (as in ants) but rather through temporal polyethism, in combination with genotypic diversification. As many as 35 effective matings have been found in colonies of $A$. dorsata (Moritz et al., 1995; Oldroyd et al., 1996) which is currently the most extreme report of polyandry in social insects. It is a basic difference between the honeybee superorganism and a multicellular organism, that its components are genetically different. But perhaps, it is exactly this crucial difference which has opened the possibility to exploit advantages through intrasuperorganismic genetic diversity; an advantage which cannot be used by multicellular organisms.

Comparatively little attention has been given to this aspect, and the significance of polyandry impact may have been underrated. The role of intracolonial genetic diversity and patriline composition on colony performance is far from clear. Page et al. (1989) developed a deterministic two-locus model for increased colonial fitness through genetic specialist workers. There is sufficient evidence that nonlinear worker interactions occur in a variety of social behaviors including hygienic behavior (Trump et al., 1967), hoarding behavior (Moritz and Hillesheim, 1989), and the alarm response (Moritz and Southwick, 1987; GuzmánNovoa and Page, 1994). In some studies intracolonial genotypic variability was positively correlated with performance (Kolmes et al., 1989; Oldroyd et al., 1992; Fuchs and Schade, 1994), but in others this was not the case. Page et al. (1995) found mostly intermediate phenotypes in genotypically mixed colonies, but also observed that genotypically variable colonies displayed more average phenotypes thus behaving less 'chaotically' and more homeostatically. In a recent study on a large number of colonies with naturally mated queens, Neumann and Moritz (1996) estimated only $10 \%$ of honey production to be determined through the mating frequency of the queen. This weak contribution was not significantly different from zero. In addition, effects of genotypic variability on group efficiency were not necessarily always positive. Moritz and Hillesheim (1989) found that increased genotypic variability in experimental groups reduced the ability of hoarding behavior. Fuchs et al. (1996) reported a decreased ability of anti-parasite behavior in colonies of increased worker variability. Obviously although effects at the colonial level can take many different forms, they have one thing in common: they are difficult to detect. This empirical deficiency, however, certainly does not rule out their possible impact during long-term evolution. 


\subsection{Evolution of polyandry}

Colony advantages of genotypic diversity might even provide a possible explanation of their main cause, which is the polyandry of the honeybee queen. We modeled how extreme polyandry can evolve on the basis genotypic task specialization (Fuchs and Moritz, unpublished data; figure I). Because alleles coding for specialists are rare by definition, the queen needs to mate with many males to make

a.)

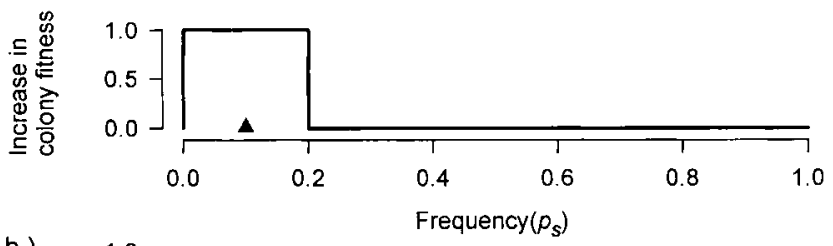

b.)

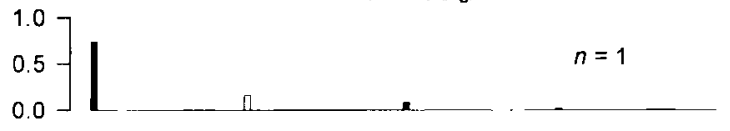

$\frac{2}{0}$
$\frac{0}{8}$
$\frac{0}{0}$
$\frac{1}{2}$
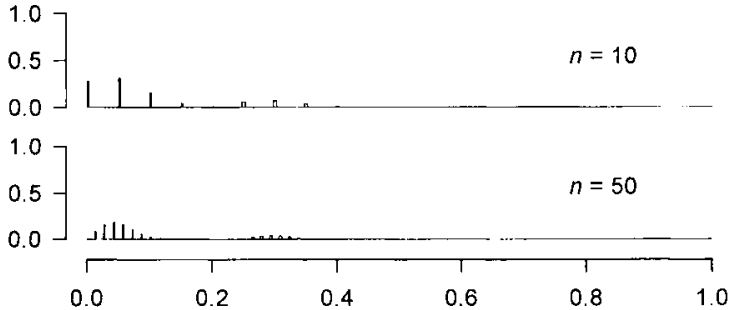

c.)

Frequency $\left(p_{s}\right)$

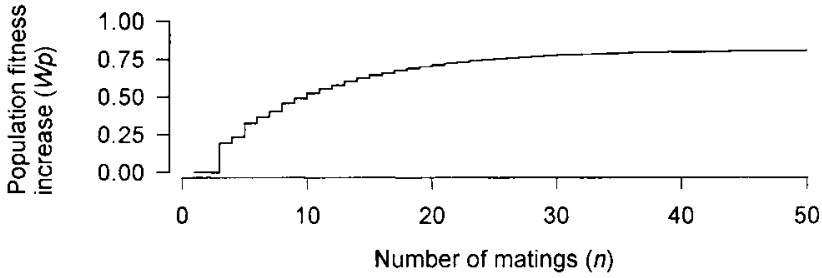

Figure 1. Model for the evolution of extreme polyandry by genetic task specialization. (a) Colony fitness is assumed to be increased if the intracolonial frequency of a gene for worker specialization $\left(P_{s}\right)$ is $>0$ but $\leq 0.2$. The frequency of that gene in the population is assumed to be $0.1(\boldsymbol{A})$. (b) Proportions of $P_{s}$ and their frequencies expected with random mating of homozgous ++ queens (black columns), heterozygous $+s$ queens (open collums), and homozygous ss queens (too rare to show) in Hardy-Weinberg equilibrium, and assuming that the number of $s$ drones within the matings follow a binomial distribution. Distributions are shown for 1, 10 and 50 matings from top to bottom, respectively. With increasing numbers of matings, $P_{s}$ is more frequently within the window of colony fitness increase. (c) Mean increase of population fitness $\left(W_{p}\right)$ in relation to the numbers of matings. At least three matings are required to increase population fitness, and increase continues with more than ten matings. As a rule, narrowing the fitness window would shift the region of population fitness increase towards higher mating frequencies. 
sure she samples at least one male which carries the desired rare specialist allele. At the same time she needs to mate with many males to keep the specialist allele at a low intracolonial frequency. A high specialist allele frequency in the colony with too many specialist workers may be detrimental. The argument is thus based on the idea that both a complete lack of specialists and too many specialists have a negative effect on colony fitness. We thus have a case of intracolonial frequency-dependent selection similar to that modeled by Moritz (1989). In fact from the numerous hypotheses for the evolution of polyandry [for a recent review see Boomsma and Ratnieks (1996)] the 'genetic specialist model' is currently the only genetic model which can plausibly predict the extremely high mating frequencies found in honeybees.

\section{CONCLUSIONS}

The social organization of the honeybee colony takes a next step in evolution, in organizing thousands of individuals into a tightly integrated superorganism. This can be compared to multicellular organisms in many aspects. Some comparisons are superficial, as composition of dependent subunits, the allocation of sexual functions to a minority, or a degree of local structuring. However, we argue that colonies can be envisaged as vehicles for genes similar to individuals, provided that sufficient genetic homogeneity is maintained through the genetic bottlenecks of reproduction. It makes sense to talk about organisms to indicate that individual cells are an integral part of a higher organizational level. Selection within or between cells steps far back behind selection at the organismal level. Obviously the honeybees have reached the next level of complexity, where the individuals are integral parts of the colony, and selection primarily operates on the colonial level. While this does not exclude intracolonial selection processes, and these are in fact well known (Moritz et al., 1996), it does however mean that selection at the colonial level is epistatic over intracolonial selection processes. If the colony dies, it does not make any difference which individual had won the intracolonial competition for reproduction and had pursued the most successful tactics. The best example that colony fitness sets the scene for selection may come from applied bee breeding. Beekeepers design the breeding schemes by selecting queens from the best colonies. If they had a means to determine the best queens without testing the colony, they would certainly take advantage. Alas, neither beekeepers nor nature can select the properties of a colony from the phenotype of a newly mated queen.

Organisms and superorganisms are organized by similar principles. Several different mechanisms interact, and the complex picture is governed through clear signal chains on the one hand and selforganized patterns on the other. The signal chains are relatively easy to identify because we can identify chemical compounds that release a certain behavior. It is then possible to argue that the active pheromonal compounds resulted from adaptive selection at the individual or colony level. Much more intricate is the search for adaptive processes in self-organized behavioral patterns. The patterns emerge as a result of the interactions of the bees in the social group. The colonial phenotype is determined by the numbers of workers involved in a task, and by threshold values and variability, leaving the individual worker and its quality rather insignificant. Returning to the analogy between organism and superorganism, in a vertebrate brain it is not so much the quality of individual neurons rather than the sheer number of neurons which makes it work. 


\section{ACKNOWLEDGEMENTS}

We are grateful to R.E. Page for stimulating discussions, which helped to clarify many of the aspects addressed in this paper.

Résumé - L'organisation des colonies d'abeilles mellifères. Caractéristiques et conséquences du concept de superorganisme. Les colonies d'abeilles vivent en sociétés très denses où chaque individu est fortement intégré sur le plan comportemental et dépendant pour sa survie et sa reproduction. Ces sociétés ont souvent été désignées par le terme de superorganisme par analogie avec les organismes supérieurs, complexes et multicellulaires. Des analogies de structure, telles que la constitution à partir de sous-unités, la reproduction limitée à quelques-unes de ces sous-unités et la sous-organisation locale sont d'ordre purement phénoménologique et peuvent être trompeuses. Beaucoup plus significatives sont en revanche les analogies des mécanismes d'évolution. Au sein du concept de l'activité génique comme relation logique entre un gène et un effet externe et de l'individu comme unité de sélection, l'évolution des superorganismes $s$ 'inscrit sans contradiction dans la théorie synthétique de l'évolution. De fait il existe des parallèles qui aident à approfondir la compréhension de la coopération entre les cellules d'un organisme. La comparaison des principes organisationnels met en évidence des analogies mais aussi des différences. De vastes processus d'auto-organisation et de réaction aux conditions locales jouent un rôle important dans la coordination de l'activité des sous-unités chez les organismes et les superorganismes. Au niveau suivant les boucles de rétroaction et l'action combinée non additive des composants ont de l'importance. Les fonctions hiérarchiques de régulation dans le domaine des phéromones ressemblent à celles des hormones chez les organismes supérieurs, bien qu'il manque une structure centrale hautement développée de régulation telle que le système nerveux chez les animaux supérieurs. La différenciation et la division du travail jouent un rôle important. Les cellules d'un organisme se différencient très largement en des types morphologiques variés, mais tel n'est pas le cas chez la plupart des insectes sociaux. À la place, existe la plupart du temps un système de division temporaire du travail. En effet il existe chez les insectes sociaux la possibilité d'une différenciation génétique des ouvrières, dont les conséquences et le potentiel de développement ne sont compris que dans leurs rudiments et sont peut-être sous-évalués ; chez les colonies d'abeilles en particulier, où il y a accouplement multiple de la reine, cet aspect pourrait revêtir un rôle important. Les recherches portant sur les conséquences de la variabilité génétique plus ou moins forte des ouvrières ou des fratries qui coopérent de façon spécifique non additive ont donné jusqu'à présent une image contradictoire ; il existe néanmoins des données qui indiquent que ces effets ont un certain impact. L'une des conséquences théoriques pourrait être que la variabilité génétique soutient les processus d'auto-organisation et d'émergence d'une structure. Une autre conséquence est que l'accouplement multiple de la reine avec un grand nombre de mâles dérive sans aucun doute de la possibilité d'exploiter les avantages d'un nombre réduit de spécialistes génétiques. Les colonies d'abeilles présentent donc de fortes similitudes avec les organismes supérieurs, ce qui justifie la notion de superorganisme et de progression vers la complexité supérieure. Tandis que les principes de structure, d'évolution et d'organisation concordent très largement, il résulte de la diversité génétique des composants des possibilités d'évolution; de plus amples recherches sont nécessaires pour préciser dans quelle mesure et de quelle façon elles sont utilisées par les colonies d'abeilles. (C) Inra/DIB/AGIB/Elsevier, Paris 
Apis mellifera / organisation sociale / superorganisme / division travail / autoorganisation / polyandrie

\section{Zusammenfassung - Organisation von} Bienenvölkern: Charakteristiken und Konsequenzen eines Superorganismuskonzeptes. Bienenvölker leben in sehr dichten und in sich weitgehend abgeschlossenen Sozietäten, auf die die einzelnen Tiere für Überleben und Reproduktion angewiesen sind. Diese Sozietäten sind in Analogie zu den aus Zellen zusammengesetzten komplexen höheren Organismen wiederholt als 'Superorganismen' bezeichnet worden. Strukturelle Analogien wie die Zusammensetzung aus Untereinheiten, die Begrenzung der Reproduktion auf wenige dieser Untereinheiten und lokale Untergliederung sind rein phänomenologisch und möglicherweise irreführend. Wesentlich tragfähiger sind dagegen Analogien der Evolutionsmechanismen. Innerhalb des Konzeptes der Genaktion als logischer Verbindung zwischen Gen und Effekt in der Außenwelt, und der damit entfallenden Fixierung auf das Individuum als Selektionseinheit ordnet sich die Evolution von Superorganismen widerspruchsfrei in die synthetische Evolutionstheorie ein. Tatsächlich ergeben sich Parallelen, die ihrerseits das Verständnis der Zusammenarbeit zwischen den Zellen eines Organismus vertiefen helfen. Der Vergleich organisierender Prinzipien zeigt Analogien auf, aber auch Differenzen. In der Koordination der Aktivität der Untereinheiten spielen bei Organismen und Superorganismen weitgehende Prozesse von Selbstorganisation und von Reaktionen auf lokale Bedingungen eine tragende Rolle. Auf der nächsten Ebene sind Rückkoppelungsschleifen und nichtadditives Zusammenwirken der Komponenten von Bedeutung. Hierarchische Steuerungsfunktionen auf der Ebene von Pheromonen ähneln der durch Hormone bei höheren Organismen, allerdings fehlt eine hochentwickelte zentrale Steuerungsstruktur, wie sie das Nervensystem höherer Tiere darstellt. Eine wichtige Rolle spielt die Differenzierung und Arbeitsteilung. Während die Zellen eines Organismus sich sehr weitgehend in morphologisch unterschiedliche Typen differenzieren, ist dies bei den meisten sozialen Insekten nicht der Fall. Stattdessen besteht zumeist ein System temporärer Arbeitsteilung. Allerdings besteht bei Insektenstaaten die Möglichkeit einer genetischen Differenzierung der Arbeiterinnen, deren Konsequenzen und Entwicklungspotentiale erst in den Anfängen verstanden sind und möglicherweise unterschätzt werden. Insbesondere bei Bienenvölkern mit einer Vielfachverpaarung der Bienenköniginnen könnte diesem Aspekt eine wichtige Rolle zukommen. Die bisherigen Untersuchungen zu Auswirkungen höherer oder geringerer genetischer Variabilität der Arbeiterinnen in den Bienenvölkern, oder spezifischer nicht-additiv zusammenwirkender, von jeweils einem Drohn abstammender Subfamilien ergaben bislang ein widersprüchliches Bild. Es zeichnet sich aber ab, daß sich diese Effekte auswirken. Eine mögliche Folge könnte sein, daß genetische Variabilität die Prozesse der Selbstorganisation und Musterbildung unterstützt. Eine weitere Folge ist, daß die Mehrfachverpaarung der Bienenkönigin mit sehr hohen Drohnenzahlen sich zwanglos aus der Möglichkeit zur Nutzung von Vorteilen aus geringen Anzahlen genetischer Spezialisten ableiten läßt. Bienenvölker weisen damit erhebliche Ähnlichkeiten mit höheren Organismen auf, die eine Bezeichnung als Superorganismus und damit als weiterer Schritt zu höherer Komplexität rechtfertigen. Während strukturelle, evolutionäre und organisatorische Prinzipien sehr weitgehend übereinstimmen, erwachsen aus der genetischen Unterschiedlichkeit der Komponenten zusätzliche Entwicklungsmöglichkeiten, 
deren Ausschöpfung bei Bienenvölkern weiterer Untersuchungen bedarf. (C) Inra/DIB/AGIB/Elsevier, Paris

\section{Soziale Organisation / Superorganis- mus / Arbeitsteilung / Selbstorganisa- tion / Polyandrie / Apis mellifera}

\section{REFERENCES}

Bonner JT (1995) Life Cycles: Reflections of an Evolutionary Biologist. Princeton Univ Press, New Jersey

Boomsma JJ, Ratnieks FLW (1996) Paternity in social Hymenoptera. Phil Trans $R$ Soc Lond $B$ 351, 941-957

Buss LW (1987) The Evolution of Individuality. Princeton Univ Press, New Jersey

Camazine S (1991) Self-organizing pattern formation in the combs of honey bee colonies. Behav Ecol Sociobiol 28, 61-76

Camazine C, Sneyd J (1991) A model of collective nectar source selection by honey bees: Self-organization through simple rules. J Theor Biol 149. 547-571

Camazine S, Sneyd J, Jenkins MJ, Murray JD (1990) A mathematical model of self-organized pattern formation on the combs of honeybee colonies. $J$ Theor Biol 147, 553-571

Collins AM, Rinderer TE, Tucker KW, Sylvester HA, Lackett JJ (1980) A model of honey bee defensive behavior. J Apic Res 19, 224-231

Dawkins R (1976) The Selfish Gene. Oxford Univ Press, Oxford, UK

Dawkins R (1982) The Extended Phenotype. Oxford Univ Press, Oxford, UK

Engels W, Adler A, Rosenkranz P, Luibke G, Franke W (1993) Dose-dependent inhibition of emergency queen rearing by synthetic )-ODA in the honey bee, Apis mellifera camica. J Comp Physiol $\mathrm{B} 163,363-366$

Free JB (1987) Pheromones of Social Bees. Cornell Univ Press, Ithaca, NY

Frisch K von (1967) Tanzsprache und Orientierung der Bienen. Springer, Berlin

Fuchs S, Schade V (1994) Lower performance in honey bee colonies of uniform paternity. Apidologie 25, 155-168

Fuchs S, Buichler R, Hoffmann S, Bienefeld K (1996) Non-additive effects on Honey bee (Apis mellifera) colony performance by artificial insemination of queens with mixed semen from drones of several bee lines (Apidae: Hymeneoptera). Proceedings of the $X X$ International Congress of Entomology, Firence, Italy
Guzmán-Novoa E, Page RE Jr (1994) Genetic dominance and worker interactions affect honeybee colony defense. Behav Ecol 5, 91-97

Hamilton WD (1964a) The genetical theory of social behavior 1. I Theor Biol 7, 1-16

Hamilton WD (1964b) The genetical theory of social behavior II. I Theor Biol 7, 17-52

Hunt GJ, Page RE, Fondrk MK, Dullum CJ (1995) major qantitative trait loci affecting honeybee foraging behavior. Genetics 141, 1537-1545

Kaatz HH, Engels W, Fischer LC Hildebrandt H (1992a) Pheromonal Control of Oogenesis in Worker Honey Bees (Benettova B, Belbic I, Soldan T, eds), Czech Acad Sci

Kaatz HH, Hildebrandt H, Engels W (1992b) Primer effect of queen pheromone on juvenile hormone biosynthesis in adult worker honey bees. J Comp Physiol B 162, 588-592

Kauffmann SA (1993) The Origins of Order: Selforganization and Selection in Evolution. Oxford Univ Press, Oxford, UK

Koeniger N (1970) Factors determining the laying of drone and worker eggs by the queen honeybee. Bee World 51, 166-169

Kolmes SA, Winston ML, Fergusson LA (1989) The division of labour among worker honey bees (Hymenoptera: Apidae): The effects of multiple patrilines. J Kans Entomol Soc 62, 80-95

Lindauer M (1952) Ein Beitrag zur Frage der Arbeitsteilung im Bienenstaat, Z Vgl Physiol 34, 299-345

Lindauer M (1954)Temperaturregulierung und Wasserhaushalt im Bienenstaat. Z Vgl Physiol $36,391-432$

Maschwitz UW (1964a) Alarm substances and alarm behavior in social Hymenoptera. Nature (Lond) 204, 324-327

Maschwitz UW (1964b) Gefahrenalarmstoffe und Gefahrenalarmierung by sozialen Hymenopteren. Z Vgl Physiol 47, 596-655

Maynard Smith J (1964) Group selection and kin selection. A rejoinder. Nature 201, 1145-1147

Moritz RFA (1989) Colony level and within colony level selection in honeybees: A two allele population model for Apis mellifera capensis. Behav Ecol Sociobiol 25, 437-444

Moritz RFA, Hillesheim E (1989) Genotypic intragroup variance and hoarding behavior in Honeybees (Apis mellifera L.). Apidologie 20, 383-390

Moritz RFA, Southwick EE (1987) Phenotype interactions in group behavior of honey bee workers (Apis mellifera L.). Behav Ecol Sociobiol 21, 53-57

Moritz RFA, Southwick EE (1992) In: Bees as Superorganisms. An Evolutionary Reality (Fine A, Forbes M, Wessels L, eds), Philosophy of Sci- 
ence Association, East Lansing, Michigan, PSA 1990 vol 2, 289-298

Moritz RFA, Kryger P (1994) Self-organization of cicadian rhythms in groups of honeybees (Apis mellifera L). Behav Ecol Sociobiol 34, 21 I-215

Moritz RFA, Kryger P, Koeniger G, Koeniger, Estoup A, Tingek S (1995) High degree of polyandry in Apis dorsata queens detected by DNA microsatellite variability. Behav Ecol Sociobiol 37, 357-363

Moritz RFA, Kryger P, Allsopp M (1996) Competition for royalty in bees. Nature 384,31

Neumann P, Moritz RFA (1996) Comparing performance data of honey bee colonies with mating frequencies of honeybee queens (Apis mellifera) using single locus DNA fingerprinting. Apidologie 27, 300-301

Oldroyd BP, Rinderer TE, Harbo JR, Buco SM (1992) Effects of intracolonial genetic diversity on honey bee (Hymenoptera: Apidae) colony performance. Ann Entomol Soc Am 85, 335-343

Oldroyd BP, Smolenski AJ, Cornuet JM, Wongsiri S, Estoup A, Rinderer TE, Crozier RH (1996) Levels of polyandry and intracolonial genetic relationships in Apis dorsata (Hymenoptera: Apidae). Ann Entomol Soc Am 89, 276-283

Page RE Jr, Mitchell S (1991) In: Self Organization and Adaption in Insect Societies (Fine A, Forbes M, Wessels L, eds), Philosophy of Science Association, East Lansing, Michigan, PSA 1990 vol 2, 289-298

Page RE Jr, Mitchell S (1998) Self organization and the evolution of division of labor. Apidologie 29, $171-190$

Page RE, Robinson GE (1991) The genetics of division of labour in the honey bee. Adv Insect Physiol 23, 117-169

Page RE Jr, Robinson GE, Calderone NW, Rothenbuhler WC (1989) Genetic structure, division of labor, and the evolution of insect societies. In: The Genetics of Social Evolution (Breed MD, Page RE, eds), Westview Press, Boulder, CO, 15-29

Page RE, Robinson GE, Fondrk MK, Nasr ME (1995) Effects of worker genotypic diversity on honey bee colony development and behavior (Apis mellifera L.). Behav Ecol Sociobiol 36, 387-396

Prigogine I, Stengers I (1980) Dialog mit der Natur. Piper, München, Zürich

Robinson GE, Page RE jr (1988) Genetic determination of guarding and undertaking in honeybee colonies. Nature (Lond) 333, 356-358

Robinson GE, Page RE jr (1989) Genetic basis for division of labor in an insect society. In: The Genetics of Social Evolution (Breed MD, Page RE, eds), Westview Press, Boulder, CO, 61-80
Rösch GA (1927) Untersuchungen über die Arbeitsteilung im Bienenstaat. I. Die Tätigkeiten im normalen Bienenstaate und ihre Beziehungen zum Alter der Arbeitsbiene, Z Vgl Physiol 6, 268-298

Rösch GA (1930) Untersuchungen über die Arbeitsteilung im Bienenstaat. I. Die Tätigkeiten der Arbeitsbienen unter experimentell veränderten Bedingungen. Z Vgl Physiol 6, 268-298

Ruttner F (1988) Biogeography and Taxonomy of Honeybees. Springer, Berlin

Seeley TD (1982) Adaptive significance of the age polyethism schedule in honeybee colonies. Behav Ecol Sociobiol 11, 287-293

Seeley TD (1986) Social foraging in honey bees: How colonies allocate foragers between patches of flowers. Behav Ecol Sociobiol 19, 343-354

Seeley TD (1989) The honey bee colony as a superorganism. Am Scientist 77, 546-553

Seeley TD (1995) The Wisdom of the Hive. Harvard Univ Press, Cambridge, MA

Smith DR (1991) Diversity in the Genus Apis. Westview Press, Boulder, CO

Southwick EE (1988) Thermoregulation in honeybee colonies. In: Africanized Honey Bees and Bee Mites (Needham G, page RE, Delfinado-Baker M, Bowman CE, eds), Wiley, New York, 223-236

Stort AC (1974) Genetic study of the aggressiveness of two subspecies of Apis mellifera in Brazil. 1. Some tests to measure aggressiveness. J Apic Res 13, 32-38

Trump RF, Thompson VC, Rothenbuhler WC (1967) Behavior genetics of nest cleaning in honeybees $V$. Effect of previous experience and composition of mixed colonies in response to disease-killed brood. J Apic Res 6, 127-131

Visscher PK (1998) Colony integration and reproductive conflict in honey bees. Apidologie 29, 23-45

Watmough J, Camazine S (1995) Self-organized thermoregulation of honey bee clusters. $J$ Theor Biol 176, 391-402

Wheeler WM (1928) The Social Insects: Their Origin and Evolution. Kegan, Paul, Trench, Trubner \& Co, London

Williams GC (1966) Adaption and Natural Selection. Princeton Univ Press, New Jersey

Wilson DS (1975) A theory of group selection. Proc Natl Acad Sci USA 72, 143-146

Wilson DS (1977) Structured demes and the evolution of group-advantageous traits. Am Nat 111, 157-185

Wilson DS, Sober E (1989) Reviving the superorganism. I Theor Biol 136, 337-356

Wilson EO (1975) Sociobiology: The New Synthesis. Harvard Univ Press, Cambridge, MA 
Wilson EO, Hölldobler B (1990) The Ants. Springer, Berlin

Winston ML, Slessor KN, Smirle MJ, Kandil AA (1989) The influence of a queen-produced substance, 9HDA, on swarm clustering behavior in the honey bee Apis mellifera L. J Chem Ecol 8 , 1283-1288

Winston ML, Higo H, Slessor KN (1990) The effect of various dosages of queen mandibular pheromone on the inhibition of queen rearing in the honey bee (Hymenoptera: Apidae). Ann Entomol Soc Am 83, 234-238

Winston ML, Higo H, Colley SJ, Pankiw T, Slessor KN (1991) The role of queen mandibular pheromone and colony congestion in honey bee (Apis mellifera $\mathrm{L}$ ) reproductive swarming. $J$ Insect Behav 4, 649-660

Wynne-Edwards VC (1962) Animal Dispersion in Relation to Social Behaviour. Oliver Boyd, Edinburgh 